\title{
Setting the Reserve Bank's Inflation Target: The New Zealand Debate
}

\author{
Paul Dalziel
}

ECTION 8 of the Reserve Bank of New Zealand Act 1989 stipulates that the
statutory objective of monetary policy is 'achieving and maintaining stability in
the general level of prices'. A more precise inflation target, against which the
performance of the Reserve Bank is judged, is contained in a Policy Targets
Agreement (PTA) negotiated by the Minister of Finance and the Governor of the
Reserve Bank whenever the Governor's contract is renewed (every five years), or if
a new Governor is appointed, or by agreement between the Minister and the Gov-
ernor.

The first PTA (dated 2 March 1990) stated that 'an annual inflation rate in the range of 0 to 2 per cent will be taken to represent the achievement of price stability' (Reserve Bank Bulletin, March 1990, p. 26), and this target band was retained in the second and third PTAs (dated 19 December 1990 and 16 December 1992 respectively). The fourth PTA, however, signed on 10 December 1996 (the day that New Zealand's first coalition government under its new proportional-representation electoral system was announced), relaxed the top end of the target band by one percentage point. This change followed widespread criticism of the way in which the Reserve Bank's policy response to a small but persistent breach of the top end of the 0-2 per cent target band throughout 1996 caused the trade-weighted exchange rate to appreciate sharply. Some commentators suggested that this might have been avoided if the range of the target band were broader and/or its midpoint higher. Other commentators, however, argued that any relaxation of the target would raise inflationary expectations, and so would be counterproductive in the medium term. The December 1996 PTA embodied what the Governor of the Reserve Bank has described as 'a reasonable compromise' (Brash, 1997:5): the target range was widened from two to three percentage points and the midpoint was lifted from 1.0 to 1.5 per cent a year. These are obviously very small changes, but the latter in particular represents a significant shift in New Zealand's monetary policy framework, which it is the purpose of this article to discuss.

\footnotetext{
'Section 12 of the Act also allows the government to change the economic objective of monetary policy by Order in Council for up to twelve months at a time. Section 12 has not been invoked in the eight years since the Act was passed, but, if it were used, a new PTA would have to be negotiated in line with the interim objective within 30 days of the Order in Council.
}

Paul Dalziel is Reader in Economics at Lincoln University. 


\section{Accountability, Flexibility and Credibility}

Three principles are central to the Policy Targets Agreement mechanism: accountability, flexibility and credibility. Accountability is the most straightforward. Positive inflation imposes a tax on money holders, and, if unanticipated, also involves a tax on creditors and a subsidy to debtors (including, of course, the Crown; net public domestic debt in New Zealand is approximately 30 per cent of GDP). As it is a fundamental constitutional principle that taxes should not be levied without the approval of parliament, both the government and the Reserve Bank should be accountable to parliament for the level of inflation they choose to allow (Kirchner, 1995:171-3; Robertson, 1996:3-9). The PTA, supplemented by a statutory requirement for six-monthly reports by the Reserve Bank Governor to a parliamentary Select Committee, is designed to ensure this accountability.

A degree of flexibility in the PTA is desirable because of unavoidable uncertainties involved in monetary policy. These uncertainties relate to the nature, frequency and size of present and future economic shocks; the lags between policy implementation and policy impact; and the behaviour over time of key parameters in the transmission mechanism between a change in the instruments of monetary policy and a change in the rate of inflation in the Consumers Price Index (CPI). These uncertainties mean that it is unrealistic to expect monetary policy to achieve a single-point inflation target (which strict accountability would otherwise require); and this, in turn, raises the possibility that it may not always be desirable to require policy-makers to offset immediately all shocks to the economy's underlying inflation rate (Dennis, 1997). Consequently, New Zealand's monetary policy framework introduces flexibility into the PTA in three important ways: (i) by allowing the Reserve Bank to permit one-off changes in the price level caused by certain prespecified supply-side shocks; (ii) by setting a target range rather than a target point for inflation; and (iii) by giving the Minister of Finance some discretion about whether to penalise the Governor of the Reserve Bank if there is a breach of this target range.

There is a strong potential for conflict between flexibility and accountability. For example, if the target range in the PTA is broadened to allow the Reserve Bank more room to accommodate a series of small adverse supply-side shocks, this provides an extra degree of flexibility when the shocks occur, but may also reduce the Bank's accountability for inflation outcomes in other periods. To evaluate the trade-offs involved in this potential conflict, economists tend to focus on the impact of accountability and flexibility on the third relevant principle: credibility (Blackburn \& Christensen, 1989, provide an excellent review of this literature). This is because the economic costs of achieving and maintaining a pre-announced measure of price stability depend critically on the credibility of the announced target, due to its impact on inflationary expectations. If an inflation target is only weakly credible, rational agents in the market place will adopt a somewhat higher inflation forecast in their economic decision-making. If policy-makers then persevere with their announced target, they thereby open up a gap between expected and actual inflation, which in turn produces a shortfall between potential and actual output as agents en- 
ter into contracts at nominal prices which (ex post) overvalue real wages, real interest rates and real exchange rates. There are therefore economic advantages to be gained if accountability and flexibility can be incorporated into the economy's monetary policy framework in such a way as to maximise the credibility of its preannounced inflation target. Much of the ongoing debate in New Zealand about the PTA rests on different views about how a low and narrow range compares with a higher and broader target in its impacts on accountability, flexibility, and hence credibility.

\section{Grounds for Flexibility in the PTA}

The PTA recognises that, in the normal course of events, an economy will experience a range of random price shocks that are 'quite outside the direct influence of monetary policy'. It therefore establishes the principle that the Reserve Bank may accommodate the direct impact of such shocks, but 'in a manner which prevents general inflationary pressures emerging'. The shocks that are explicitly recognised under this principle as 'caveats' to the Bank's CPI inflation target in the fourth PTA are as follows:

- significant changes in the terms of trade arising from an increase or decrease in either import or export prices;

- an increase or decrease in the rate of the goods and services tax, or a significant change in other indirect tax rates;

- a crisis such as a natural disaster or a major disease-induced fall in livestock numbers which is expected to have a significant impact on the price level;

- a significant price level impact arising from changes to government or local authority levies; and

- a movement in interest rates that causes a significant divergence between the change in the CPI and the change in the CPI excluding the interest costs component.

In practice, the Reserve Bank incorporates these caveats by making three adjustments to the CPI statistic each quarter. First, it removes the direct impact of interest rate changes (relying on the 'CPI excluding credit services' series published by Statistics New Zealand). Second, it removes any indirect tax change (a relatively rare event). Third, it removes any other price movement in the PTA list of caveats that in the Reserve Bank's judgment has contributed more than 0.25 percentage points to the CPI inflation rate over the previous twelve months. This calculation

\footnotetext{
${ }^{2}$ The text of the PTA can be downloaded from the site http://www.rbnz.govt.nz
} 
produces the 'underlying inflation rate', which the Reserve Bank adopts as its PTA target.

Note that the third step requires the Bank to exercise judgment in calculating the statistic by which its performance is monitored. Commentators have observed that accountability would be enhanced if an independent organisation such as Statistics New Zealand produced the underlying inflation rate statistic in a more mechanistic fashion (McCallum, 1995:5; OECD, 1996:42). The Bank agrees in principle (Roger, 1994:112), and continues to research how this might be achieved in practice (Roger, 1995). In the meantime, it has been very careful to maintain its reputation for integrity in its calculations of the underlying rate of inflation. In the year to June 1995, for example, unusually adverse climatic conditions increased the price of fresh fruit and vegetables sharply, adding 0.4 per cent to the CPI inflation rate. This moved the underlying inflation rate outside the target band then in effect (to 2.2 per cent), but the Reserve Bank made no attempt to remove the fresh fruit and vegetable price increase from its underlying inflation rate statistic, on the basis that a weather-related effect is not one of the supply-side shocks explicitly mentioned in the PTA caveats.

Further flexibility is introduced by setting a target range 'within which inflation can vary without monetary policy being deemed unsuccessful' (Dennis, 1997:22), and by allowing the Minister of Finance some discretion in determining ex post whether the Reserve Bank Governor is culpable for movements of underlying inflation outside that range. The basis for the Minister's discretion is perhaps the least clearly defined aspect of New Zealand's monetary policy framework, and has been developed in a series of letters between the Minister and the non-executive Directors of the Bank after small breaches of the 0-2 per cent target in June 1995 and again in March 1996. The position of the non-executive Directors is summarised in this extract from a letter dated 19 April 1996 written by the Reserve Bank Governor to the Minister of Finance (Reserve Bank Monetary Policy StatementJune 1996, p. 46, emphasis in original):

I think it is important that everybody recall the words of the non-executive Directors of the Bank in their letter to you last June, namely that it was their 'understanding that 0 to 2 per cent was always intended to be a target towards which the Bank would be constantly aiming, not necessarily a target which could, given the inevitable uncertainties in forecasting and lags in the effectiveness of monetary policy, always be certain of attainment'. That is certainly my understanding of what the target means, but I think it would be helpful if the wider public began to understand that also.

The Minster of Finance (Hon. Bill Birch) has been cautious in using this discretion, writing to the non-executive Directors that he regards any breach of the target range as 'serious', and asking on each occasion of a breach for a report describing its causes and explaining what remedial actions were being taken to restore price stability (Reserve Bank Monetary Policy Statement June 1996, p. 42). To date, the 
Minister has been satisfied that the Governor should not be held culpable for the breaches in 1995 and 1996. But this procedure raises a number of important issues. First, Ministerial discretion is reintroduced into the monetary policy framework, and so the attempt to divorce monetary policy from politics falters (this point is discussed more generally by McCallum, 1995:26). Second, the Minister, through the non-executive Directors of the Reserve Bank, is obliged on these occasions to investigate the technical details of whether monetary policy set six to twelve months earlier had been consistent with achieving the missed target (on the information available at the time), working against the autonomy of the Reserve Bank in designing and implementing monetary policy. Third, if the breaches become frequent, the PTA target begins to lose its credibility as an anchor for inflationary expectations. This was very important in New Zealand in 1995 and 1996, when the underlying annual inflation rate lay between 1.9 and 2.4 per cent throughout and breached the 2.0 per cent ceiling in five of the eight quarters.

\section{The Breadth of the Target Band}

The December 1996 PTA broadened the inflation target band from two percentage points to three percentage points. In terms of the discussion of the previous section, this increased the flexibility of monetary policy at the expense of reducing the Reserve Bank's accountability for outcomes in which underlying inflation is higher than two per cent but below three per cent.

The primary argument supporting the change rests on an analysis of the precision of the forecasting techniques and policy instruments available to the Reserve Bank, produced during the OECD's 1996 economic survey of New Zealand. Describing New Zealand's regime for controlling inflation as 'ambitious', the survey went on to explain the basic issues and their impact on credibility (OECD, 1996:44):

Having too narrow a band would risk missing the target sufficiently frequently to call its credibility into question. It could require implausible forecasting ability by the Reserve Bank if changes in inflationary pressure are to be detected early enough for monetary policy to react in time to prevent them driving inflation outside the band, given the quite long time lags before policy takes effect. There will thus tend to be some irreducible minimum for the variation in inflation, determined mainly by the magnitude of the shocks to which the economy is subject and the length of the lags before policy actions take effect. Attempts to go below this will tend to result in instability in the setting of monetary conditions.

Two issues are highlighted in this analysis. The first is that, even if the Reserve Bank uses best available techniques for forecasting price changes and implementing properly targeted monetary policy, the standard error in the inflation equation means that inflation can be expected to move outside any given band with a certain probability, where the probability varies inversely with the width of the band. 
Turner (1996), for example, constructs a simulation model of the New Zealand economy that suggests a band of two percentage points might be breached 20 per cent of the time, but a band of three percentage points might be breached only 5 per cent of the time. On the basis of these estimates, the December 1996 PTA change reduces the expected involvement of the Minister in investigating target breaches from once every five quarters to once every five years.

The Reserve Bank has also addressed this issue by examining alternative measures of underlying inflation with smaller variances (Roger, 1994, 1995). Possible candidates include a trimmed mean CPI or a weighted median CPI, both of which reduce the influence of large price movements in the individual components of the CPI to give a better measure of central tendency. Adopting one of these statistics as the official measure of underlying inflation, therefore, would reduce the risk of breaches of the target band caused by a temporary shock to one or more components of the CPI. It is by no means certain, however, that this change would be generally accepted by the public. The PTA explains that the CPI is used as the target because it is 'the measure that is monitored most closely by the public' and it may be difficult to justify a departure from this well-established tradition.

The second issue highlighted by the OECD analysis is that, given the standard error for inflation, the probability of a breach is minimised if the Reserve Bank continuously adjusts its policy instruments so that they always target the midpoint of the PTA band. Some commentators have argued that doing this in an uncertain environment imposes real costs on the economy, such as a higher variance in output, and so propose that the Reserve Bank should be given further flexibility (that is, a wider target band) in order to allow some modest degree of output stabilisation. Bryant, for example, argues that, while a single goal of price stability was probably desirable during the transition period from New Zealand's high inflation policies of the 1970s and early 1980s, 'the credibility advantages of complete abstinence are probably not so overwhelming as to justify keeping macroeconomic stabilisation locked up in the closet' (1996a:26). He further reports simulation analysis based on a simple macroeconomic model incorporating features of the New Zealand economy, which suggests that 'rules for monetary policy that permit output smoothing in addition to the primary goal of inflation avoidance can foster marginally improved economic performance' (1996b:33, emphasis added).

This criticism should not be overstated (and the sentence just quoted illustrates that Bryant was careful not to do so). Some significant supply-side shocks are already accommodated by monetary policy (the PTA caveats described above), while policies aimed at price stability will also promote output stabilisation in an environment of demand-side shocks. Further, s.12 of the Reserve Bank of New Zealand Act contains transparent provisions for the government to change the objective of monetary policy for up to twelve months at a time (renewable) which could be invoked to respond to any extraordinary event requiring discretionary stabilisation policy. There are, however, important scenarios where an exclusive focus on shortterm price stability might also impose higher costs than a framework that provides some scope for output stabilisation. Consider the case where annual inflation is at 
the midpoint of the target band, and the economy experiences a series of small adverse supply-side shocks not covered by the PTA caveats. Under these circumstances, a central bank concerned with output stability might decide to accommodate the shocks, or it might tolerate an easing in monetary conditions as output growth slows and unemployment rises. If, instead, the central bank is concerned solely with price stability, then it should take immediate action to offset the price rise - in order to minimise the probability of breaching the target band in the following period - even if this slows economic growth further.

This argument, of course, attacks the very core of the reform to the Reserve Bank of New Zealand Act in 1989, which stipulated price stability to be the sole statutory objective of monetary policy. Multiple policy targets would make the accountability of monetary policy-makers far less clear cut, and so would reduce the credibility of their commitment to price stability (Evans et al., 1996:1864-5). The Reserve Bank is also concerned that concessions in this direction would lead to a wider variance of inflation and so would reintroduce costs that the current framework is designed to avoid (Ebert, 1994). Thus, the Reserve Bank Governor has been at pains to emphasise that the Bank remains firmly committed to targeting the middle part of the PTA range (Brash, 1996b:3; 1997:5), so that the move to a three percentage point PTA band does not signal any intention to engage in output stabilisation.

To summarise: the broadening of the inflation target band does not represent a significant change in policy. It simply adjusts the upper point at which the Reserve Bank must justify its performance to the Minister of Finance, and is now more in line with reasonable expectations about the ability of the Bank to forecast and control inflation with the instruments at its disposal. More significant is the associated rise in the midpoint of the range, which means that the Bank is now 'aiming at' 1.5 per cent instead of 1.0 per cent (Brash, 1996b:3). It is universally recognised that the CPI underestimates over time both quality improvements in goods and services and the ability of consumers to substitute towards cheaper products in response to relative price changes; and it is therefore accepted that price stability is consistent with a small amount of inflation in the CPI. The policy in New Zealand used to be that the midpoint of the PTA target band should equal this measurement bias, which was assumed to be about 1 per cent (Dawe, 1990:32; Brash, 1996a:312). This is no longer the case. The New Zealand Government Statistician advises that the bias in the New Zealand CPI is certainly less than the bias in the United States CPI, recently estimated to be 1.1 per cent, and so is below the revised midpoint of the PTA target band. ${ }^{3}$ For the first time since the 1989 reform, therefore, policymakers are now willing to accept ongoing inflation above the bias in the CPI, and the reasons for this change need careful examination.

\footnotetext{
${ }^{3}$ I am grateful to an anonymous referee for this point, confirmed in Brash (1997:4).
} 


\section{The Midpoint of the Target Band}

The debate about the optimal midpoint of the PTA target band centres on whether the monetary policies required to maintain strict price stability (after allowing for the CPI measurement bias) impose real costs on the economy that could be avoided by accepting a small amount of positive inflation. The position previously taken by the Reserve Bank (Archer, 1994) is the orthodox 'natural rate hypothesis' or 'quantity theory of money' that holds that monetary policy has no long-run impact on the levels of real output and employment, but monetary expansion beyond the economy's real growth rate is eventually reflected in equivalent increases in the price level only. This position has not gone entirely unchallenged in New Zealand; the late Jan Whitwell (1987, 1990, 1992), for example, consistently argued for nonmonetary theories of inflation, while in Dalziel $(1991,1992,1993)$ I argued that the process of monetary disinflation could have persistent real effects through hysteresis in the labour market and in the tradables sector. Nevertheless, the focus of the debate in New Zealand in recent years has tended to be not so much on the link between inflation and the level of output (an exception is NZIER, 1996:11), but on the link between inflation and long-term output growth.

Since New Zealand's experience with price stability is too short to allow econometric investigation of this link, the debate has been fuelled by international empirical studies. Stanley Fischer's address to the Bank of England's Tercentenary Symposium (reprinted as Fischer, 1996) has been particularly influential. Fischer cites his 1993 cross-country study to observe that 'the evidence points strongly to a predominantly negative longer-term relationship between growth and inflation' (Fischer, 1996:278, emphasis in original). Fischer's statistical evidence is unable to establish causality, but a plausible transmission mechanism is supported by his data, whereby higher inflation is associated with lower capital accumulation and lower productivity growth. More recently, however, another cross-country study by Michael Sarel comes to a different conclusion (Sarel, 1996:200):

... this paper explores the possibility of non-linear effects of inflation on economic growth, and finds evidence of a structural break in the function that relates growth rates to inflation. When inflation is low, it has no significant effect on economic growth; the effect may even be slightly positive. But when inflation is high, it has a powerful negative effect on growth. The structural break is estimated to occur where the average annual rate of inflation is $\mathbf{8}$ per cent. ... [Thisl suggests a specific target for policy: keep inflation below the structural break.

Sarel's results (see also the study by Akerlof et al., 1996) have rekindled the debate about whether policy-makers should be more relaxed about allowing a small rate of anticipated inflation to emerge in the economy. Arguments in favour of this rest on the general hypothesis that modern economies have a positive inflationary bias which can be contained only by restrictive monetary conditions that impose real costs. The mainstream theory advocated to explain this holds that workers ef- 
fectively resist nominal wage cuts and uncompensated productivity increases, but are less able to prevent real wage cuts through higher consumer prices. Hence, it is argued, most relative price adjustments in the labour market take place through wage increases for workers in high demand rather than through wage cuts for workers in excess supply (see, for example, Krugman, 1996; empirical evidence in support of the downward nominal wage rigidity hypothesis in New Zealand has been presented by Cassino, 1995, and Chapple, 1996). This line of reasoning has been strongly resisted by the Reserve Bank (see, for example, Archer, 1994; Brash, 1996a, and Monetary Policy Statement, December 1996, pp. 5-7), partly by denying that workers resist uncompensated productivity growth when effective real wages must fall, and partly by arguing that the empirical evidence for downward nominal wage rigidity in the past was a result of high inflationary expectations under the old monetary policy framework. The Reserve Bank argues that costly nominal wage rigidities of this type will weaken over time, assisted in the New Zealand context by the Employment Contracts Act 1991, once people experience continuing price stability and learn to expect it to endure.

These arguments among monetary theorists have strong implications for the wider credibility debate. If, in the long run, monetary policy has no real economic effects, then a decision by a government to raise the target midpoint to allow a positive (albeit small) amount of ongoing inflation can mean only that the government is not as firmly committed to price stability as before. This sends a signal to markets that the Reserve Bank will not be under as much political pressure to produce price stability as before, and expectations may rise to the top end of the revised inflation target band (or even higher, if it is assumed that the Minister of Finance might use his or her discretion to excuse small breaches of the inflation band ceiling). This outcome would cause real costs if the Bank continued to target the midpoint of the band, since it would produce a positive gap between expected and actual inflation (as discussed in the introduction above). Consequently, the Governor in New Zealand has used public occasions since the new PTA to stress that despite the higher target, 'the Reserve Bank has not gone soft on inflation' (Brash, 1997:5; see also Brash, 1996b).

If, however, an economy does suffer a persistent inflationary bias, then price stability can be maintained only at the expense of real costs in certain sectors of the economy (the agriculture sector, for example, or the tradables manufacturing sector). In the New Zealand context, monetary policy is thought to be unfair because the Reserve Bank's response to inflationary pressure has its primary impact on the tradables sector (due to policy-induced appreciations of the exchange rate) when in recent years the primary source of the inflationary pressure has been in the nontradable sector. The threat of political backlash against this outcome also undermines the credibility of the commitment to price stability, and so raises inflationary expectations. If the Bank remains focused on zero inflation under these circumstances, again a gap opens up between expected and actual inflation, with an associated decline in economic activity. To counter these effects, the Reserve Bank in August 1996 and December 1996 published two pamphlets, The Impact of Mone- 
tary Policy on Farming and The Impact of Monetary Policy on Exporters, seeking to allay the concerns being raised in the agriculture and tradables sectors respectively.

These considerations have profoundly different implications for the optimal PTA band. If monetary policy has no persistent effects on output and employment, policy credibility would be enhanced if the bias-adjusted measure of price stability were made the midpoint of the PTA band. If, however, the economy suffers from a positive inflationary bias that cannot be reduced, then policy credibility would be enhanced if this bias was included in the framework of analysis used to set the midpoint of the target somewhere above the bias-adjusted measure of price stability. The New Zealand increase in the PTA midpoint from 1.0 to 1.5 per cent therefore represents an important shift in the attitude of policy-makers away from a strict reliance on the former hypothesis towards a cautious acceptance that the latter hypothesis may have some validity.

\section{Conclusion}

The revised inflation target in New Zealand's December 1996 PTA widens the target band for the underlying CPI inflation rate from two to three percentage points, and raises its midpoint from 1.0 to 1.5 per cent. In this article it is argued that the widening of the band represents only a technical adjustment to reflect the unavoidable uncertainties in monetary policy and inflation forecasting; in particular, the Reserve Bank has made it clear that it does not signal a move towards using monetary policy for any degree of short-term output stabilisation. It is also argued, however, that the increase in the target midpoint represents a significant change in attitude by policy-makers towards an acceptance that a small amount of fully anticipated inflation may not be harmful in a modern market economy. Hence, it is possible that the costs of achieving and maintaining strict price stability do not outweigh the benefits.

This last proposition, of course, remains controversial, and the debate surveyed in this article will continue. Nevertheless, it is noteworthy that in the five years after the first achievement of underlying inflation within New Zealand's former target band of 0-2 per cent (December 1991), the Reserve Bank did not produce underlying CPI inflation below 1.1 per cent in any of the following 20 quarters, and the average value (on a quarterly basis) was 1.7 per cent a year. Recently, underlying inflation was 2.0 per cent or higher in seven of the eight quarters of 1995 and 1996, and the Rescrve Bank policy to correct this imposed significant burdens on New Zealand's agriculture and manufacturing sectors. This history inevitably weakened the credibility of 1.0 per cent as a midpoint for the target band, and the increase to 1.5 per cent is a cautious response by policy-makers to the problems this loss of credibility causes for monetary policy. The revised midpoint is still below that being targeted by the Reserve Bank of Australia (2.5 per cent) and the Bank of England ('2.5 per cent or less'). It will be interesting to discover whether it can be achieved by the Reserve Bank on average over the next business cycle or two without any further weakening of political support (a necessary condition for establishing the 
credibility of this target), or whether future experience will create pressures for a further increase in the midpoint of the PTA target band.

\section{References}

Akerlof, G., W. Dickens \& G. Perry (1996), 'The Macroeconomics of Low Inflation', Brookings Papers on Economic Activity 1: 1-76.

Archer, D. (1994), 'Monetary Policy, Output and Employment', Reserve Bank Bulletin 57(4): 322-9.

Blackburn, K. \& M. Christensen (1989), 'Monetary Policy and Policy Credibility', Joumal of Economic Literature 27(1): 1-4.5.

Brash, D. (1996a), 'Modern Central Banking. Discussion', pp. 309-15 in F. Capie, C. Goodhart, S. Fischer \& N. Schnadt, The Future of Central Banking, Cambridge University Press, Cambridge.

(1996b), 'Notes for Briefing Journalists at the Release of the December 1996 Monetary Policy Statement, 17 December 1996', Reserve Bank, Wellington.

(1997), 'The New Inflation Target, and New Zealanders' Expectations about Inflation and Growth', Reserve Bank Bulletin 60(1): 3-8.

Bryant, R. (1996a), 'Central Bank Independence, Fiscal Responsibility, and the Goals of Macroeconomic Policy: An American Perspective on the New Zealand Experience', Victoria University of Wellington Foundation, Wellington.

- (1996b), 'Alternative Rules for Monetary Policy and Fiscal Policy in New Zealand: A Preliminary Assessment of Stabilization Properties', Reserve Bank of New Zealand Discussion Paper Series, No. G96/3, Wellington.

Cassino, V. (1995), 'The Distributions of Price and Wage Changes in New Zealand', Reserve Bank of New Zealand Discussion Paper Series, No. G95/6, Wellington.

Chapple, S. (1996), 'Money Wage Rigidity in New Zealand', Labour Market Bulletin 2: 23-50.

Dalziel, P. (1991), 'The Rhetoric of Treasury: A Review of the 1990 Briefing Papers', New Zealand Economic Papers 25(2): 259-74.

(1992), 'National's Economic Strategy', pp. 19-38 in J. Boston \& P. Dalziel (eds), The Decent Society? Essays in Response to National's Economic and Social Policies, Oxford University Press, Auckland.

—- (1993), 'The Rhetoric of Treasury: Reply', New Zealand Economic Papers 27(1): 89-97.

Dawe, S. (1990), 'Reserve Bank of New Zealand Act 1989', Reserve Bank Bulletin 53(1): 29-36.

Dennis, R. (1997), 'Bandwidth, Bandlength, and Inflation Targeting: Some Observations', Reserve Bank Bulletin 60(1): 22-6.

Ebert, C. (1994), 'Defining Price Stability: What Should We Aim For?', Reserve Bank Bulletin 57(1): 23-34.

Evans, L., A. Grimes \& B. Wilkinson with D. Teece (1996), 'Economic Reform in New Zealand 1984-95: The Pursuit of Efficiency', Journal of Economic Literature 34(4): 1856-902. 
Fischer, S. (1993), 'The Role of Macroeconomic Factors in Growth', Journal of Monetary Economics 32(3): 485-512.

(1996), 'Modern Central Banking', pp. 262-308 in F. Capie, C. Goodhart, S. Fischer \& N. Schnadt, The Future of Central Banking, Cambridge University Press, Cambridge.

Kirchner, S. (1995), 'Central Bank Independence and Accountability: The New Zealand Case', Agenda 2(2): 169-80.

Krugman, P. (1996), 'Stable Prices and Fast Growth: Just Say No', Economist, August 31: 15-18.

McCallum, B. (1995), 'New Zealand's Monetary Policy Arrangements: Some Critical Issues', Reserve Bank of New Zealand Discussion Paper Series, No. G95/4.

New Zealand Institute of Economic Research (NZIER) (1996), Quarterly Predictions, September 1996, Wellington.

Organisation for Economic Co-operation and Development. (OECD) (1996), OECD Economic Surveys: New Zealand, Paris.

Robertson, B. (1996), "The Currency and the Constitution: Lessons From "A Rather Small Place", Oxford Journal of Legal Studies 16(1): 1-29.

Roger, S. (1994), 'Alternative Measures of Underlying Inflation', Reserve Bank Bulletin 57(2): 109-29.

(1995), 'Measures of Underlying Inflation in New Zealand, 1981-95', Reserve Bank of New Zealand Discussion Paper Series, No. G95/5, Wellington.

Sarel, M. (1996), 'Non-linear Effects of Inflation on Economic Growth', IMF Staff Papers 43(1): 199215.

Turner, D. (1996), 'Inflation Targeting in New Zealand: What is the Appropriate Bandwidth', Reserve Bank of New Zealand Monetary Policy Workshop (20-21 May).

Whitwell, J. (1987), 'Monetary Policy With A Deregulated Financial Sector', pp. 261-82 in A. Bollard \& R. Buckle (eds), Economic Liberalisation in New Zealand, Allen \& Unwin with Port Nicholson Press, Wellington.

- (1990), 'The Rogernomics Monetarist Experiment', pp. 101-22 in M. Holland \& J. Boston (eds), The Fourth Labour Govemment Politics and Policy in New Zealand (2nd ed.), Oxford University Press, Auckland.

- (1992), 'Money and Inflation: Theories and Evidence', pp. 192-222 in S. Birks \& S. Chatterjee (eds), The New Zealand Economy: Issues and Policies (2nd ed.), Dunmore Press, Palmerston North.

I am grateful to the editor for his invitation to submit this article and for very helpful discussions on its theme. I am also grateful to Simon Chapple, David Gruen, Michael Sarel, Mark Stone and two anonymous referees for very perceptive and helpful comments on an earlier draft of the article, and to Mark Fox and David Turner for providing references that have been incorporated into this published version. The usual caveats apply. 